\title{
Komunikasi Partisipatif dalam Pengembangan Kewirausahaan Sosial di Pandeglang, Banten
}

\author{
Irpan Ripa'i Sutowo
}

\author{
Program Studi Ilmu Komunikasi, UPN Veteran Jakarta \\ Email: irpan.sutowo@upnvj.ac.id
}

\section{How to Cite This Article:}

Ripa'i Sutowo, Irpan. (2020). Komunikasi
Partisipatif Dalam Pengembangan
Kewirausahaan
Banten. Expose: Jurnal Ilmu Komunikasi,
3(1), 21-43. DOI: 10.33021 /exp.v3i1.885

English Title: Participatory Communication in the Development of Social Entrepreneurship in Pandeglang, Banten
Received: 02-12-2019

Revision: 26-04-2020

Acceptance: $10-05-2020$

Published online: 12-05-2020

\begin{abstract}
Abstrak. Salah satu pemangku kepentingan pembangunan yang peduli dalam menangani masalah sosial di Kabupaten Pandeglang adalah organisasi sosial kemanusiaan Harapan Dhuafa (Pandhu) cabang Pandeglang. Penelitian ini betujuan untuk mengetahui komunikasi partisipatif dalam pengembangan kewirausahaan sosial di Pandeglang, Banten. Pengambilan sampel dilakukan dengan sensus, yaitu sebanyak 56 responden. Pendekatan penelitian disusun dengan menggunakan metode penelitian kombinasi. Data dikumpulkan dengan menggunakan metode sensus, wawancara mendalam, dan observasi. Analisis data menggunakan statistik deskriptif dengan tabel frekuensi dan persentase. Hasil penelitian melalui wawancara mendalam menemukan bahwa komunikasi partisipatif dalam pengembangan pertanian padi organik dengan menggunakan metode system of rice intensification (SRI) organik telah menunjukkan dampak positif pada pengembangan kewirausahaan sosial di Desa Parigi. Berdasarkan hasil survei mengunakan instrumen kuesioner terstruktur kepada responden petani penerima manfaat (PPM) program padi organik SRI didapat intensitas komunikasi partisipatif dengan indikator dialog, voice, liberating pedagogy, dan action-reflection-action sebagian besar berkategori tinggi yaitu masing-masing sebesar $57,14 \%$; $73,21 \%$; $98,21 \%$; dan $76,79 \%$.
\end{abstract}

\section{Kata kunci: petani padi organik, komunikasi partisipatif, kewirausahaan sosial.}

Abstract. One of the development stakeholders who concern in dealing with social issues in Pandeglang Regency is the social organization of the Harapan Dhuafa (Pandhu) branch of Pandeglang. This study aims to determine participatory communication in the development of social entrepreneurship in Pandeglang, Banten. The sampling was done by a census of 56 respondents. The research approach was prepared using a combination of research methods. The data were collected using census methods, in-depth interviews, and observations. The data analysis used descriptive statistics with frequency and percentage tables. The results of the study through in-depth interviews found that participatory communication in the development of organic rice farming using the organic system of rice intensification (SRI) method has shown a positive influence on the development of social entrepreneurship in Parigi Village. Based on the survey 
results using a structured questionnaire instrument to beneficiary farmer respondents (PPM) of the SRI organic rice program, it was found that the intensity of participatory communication with indicators of dialogue, voice, liberating pedagogy, and action-reflection-action was mostly high, each at $57.14 \% ; 73.21 \% ; 98.21 \%$; and $76.79 \%$, respectively.

Keywords: organic rice farmers, participative communication, social entrepreneurship, sociopreneurship

\section{PENDAHULUAN}

Indonesia merupakan salah satu negara berkembang yang hingga saat ini begitu banyak permasalahan sosial secara luas yang sedang dihadapi seperti kemiskinan, korupsi, penegakan hukum yang lemah, rendahnya mutu pendidikan, kerusakan lingkungan, kemacetan, pengangguran, kesehatan dan sanitasi, dan lain sebagainya. Masalah sosial dan implementasi program pembangunan ini merupakan sebuah tanggungjawab bersama yang harus secepatnya dilaksanakan hingga tercapainya kesejahteraan sosial yang diharapakan. Begitu banyak permasalahan sosial yang dihadapi Indonesia, sehingga pembangunan mensyaratkan adanya pelibatan atau partisipasi seluruh masyarakat maupun pemangku kepentingan pembangunan. Mardikanto (2010) mengartikan istilah pembangunan sebagai suatu proses atau rangkaian kegiatan yang tidak pernah kenal henti, untuk mewujudkan perubahanperubahan dalam kehidupan masyarakat hingga tercapainya perbaikan kesejahteraan sosial pada situasi dan kondisi lingkungan kehidupan yang senantiasa terus mengalami perubahan-perubahan. Partispasi masyarakat maupun pemangku kepentingan pembangunan dimulai sejak pengambilan keputusan tentang perencanaan pembangunan, sampai pada pelaksanaan dan pengawasan kegiatan, serta pemanfaatan hasil pembangunan oleh masyarakat. Masyarakat maupun pemangku kepentingan pembangunan yang dimaksud berpartisipasi aktif yaitu meliputi aparat pemerintah, tokoh-tokoh masyarakat, pekerja sosial, aktivitas lembaga swadaya masyarakat (LSM), dan perorangan atau kelompok/organisasi sosial. Kemunculan paradigma baru komunikasi pembangunan yang partisipatif menjelaskan bahwa semua pihak pemangku kepentingan memiliki peran partisipasi dalam proses perencanaan sampai dengan pengambilan keputusan. Pemangku kepentingan pembangunan utama yang sering terlupakan, yaitu masyarakat yang selalu diposisikan sebagai objek pembangunan bukan dijadikan subjek. Komunikasi partisipatif dilaksanakan dalam model komunikasi horizontal dimana komunikasi yang terjadi di masyarakat selain saling memberikan informasi, ide, dan pendapat juga terjadi sebuah dialog yang menghasilkan suatu kesepakatan bersama. 
Komunikasi partisipatif adalah suatu proses komunikasi dimana terjadi komunikasi dua arah atau dialogis, sehingga menghasilkan suatu pemahaman sama terhadap pesan yang disampaikan. Secara historis, gagasan lahirnya komunikasi partisipasi diilhami oleh pemikiran intelektual dari Amerika Latin terutama Paulo Freire, kemudian diikuti oleh Luis Ramiro Beltran, dan Juan Diaz Bordenave. Intelektual tersebut beranggapan bahwa paradigma modernisasi tidak relevan atau bahkan membahayakan. Istilah Participatory Communication sendiri pertama kali digunakan secara resmi dalam sebuah seminar di Amerika Latin pada tahun 1978 yang disponsori oleh Center for Advanced Studies and Research for Latin America (Huesca dalam Hadiyanto 2008).

Komunikasi partisipatif lekat dengan model komunikasi yang berisi lima konsep utama, yaitu (1) dialog, (2) penyadaran (conscientization), (3) praxis, (4) perubahan (transformation), dan (5) kesadaran kritis (critical consciousness) (McPhail 2009). Menurut Tufte dan Mefalopulos (2009), terdapat empat prinsip dasar yang melandasi proses komunikasi partisipatif. Keempat prinsip tersebut, harus saling mendukung satu sama lainnya dalam sebuah program pembangunan partisipatif. Sebab, tanpa mengandalkan prinsip-prinsip tersebut komunikasi partisipatif tidak akan berjalan sebagaimana mestinya, yang menyebabkan tidak optimalnya suatu program atau kegiatan pembangunan. Prinsip dasar tersebut adalah: (1) dialog, (2) voice, (3) liberating pedagogy dan (4) action-reflection-action.

Dialog, kebebasan dan keterbukaan dalam dialog merupakan prinsip dasar komunikasi partisipatif. Liliweri (2011) menyebutkan bahwa dialog merupakan komunikasi terstruktur yang mengandalkan perhatian penuh, mendengarkan secara aktif tentang akar yang paling dalam dari perasaan, keyakinan dan pengalaman. Menurutnya, dalam dialog tidak hanya melibatkan pikiran, tetapi terutama hati. Dialog tertarik pada hubungan antara peserta yang hatinya terikat oleh topik atau tema yang dapat dieksplorasi bersama.

Voice merupakan pusat dari komunikasi dialogis adalah penyadaran atas kekuatan hubungan antar manusia. Voice atau penyampaian aspirasi menekankan pada adanya ruang dan waktu bagi masyarakat, terutama masyarakat yang termarjinalkan untuk diperhatikan dalam menyuarakan pendapat, menerjemahkan 
masalah-masalahnya, merancang solusi, untuk kemudian melakukannya bersamasama (Tufte \& Mefalopulos 2009).

Liberating Pedagogy merupakan cara seseorang dalam berkomunikasi yang dilakukan dengan proses dialogis untuk membantu menyalurkan aspirasinya. Freire (2005) menyebutkan terdapat empat pilar dari liberating pedagogy yang terkait dengan komunikasi, yaitu; (a) cinta, (b) kerendahan hati (membuang arogansi), (c) kepercayaan, dan (d) harapan. Hasil dari liberating pedagogy disebut Freire sebagai "scientilizacao", yang dapat diterjemahkan sebagai pencapaian kesadaran "actionoriented" atau mencapai kesadaran yang berorientasi pada tindakan. Muslikhah (2015) menambahkan proses liberating pedagogy atau pembelajaran yang membebaskan ini dimaknai bukan hanya sekedar membantu memfasilitasi penyaluran aspirasi ataupun proses diseminasi informasi dari yang tidak tahu menjadi tahu, melainkan lebih kepada bagaimana cara membentuk sebuah dialog, sehingga mampu mengidentifikasi masalah secara bersama dan menetapkan solusi yang akan diambil.

Action-Reflection-Action merupakan kegiatan dalam merefleksikan masalah dan melakukan tindakan dengan mencoba menghimpun gerakan dari masalah yang diidentifikasi dalam sebuah komunitas/kelompok. Kata kunci dalam konsep ini adalah meningkatkan kesadaran dan komitmen untuk bertindak dalam sebuah kelompok. Hal tersebut bisa dicapai dengan melibatkan tindakan kolektif dalam kelompok yang mempunyai komitmen dan rasa memiliki pada masalah yang dihadapi (Tufte \& Mefalopulos 2009; Muslikhah 2015).

Penelitian yang dilakukan oleh Muchtar (2016) menjelaskan komunikasi partisipatif merupakan salah satu pendekatan untuk mewujudkan tujuan pembangunan melalui partisipasi aktif masyarakat. Komunikasi yang berusaha membangkitkan gairah masyarakat ini dirangkul melalui komunikasi akar rumput dibumbuhi oleh kebijakan dan intervensi pemerintah. Wujud pelaksanaan komunikasi partisipatif adalah "kegiatan masyarakat yang didukung oleh pemerintah", bukan sebaliknya, "program pemerintah yang dilaksanakan oleh masyarakat". Dijelaskan juga pada beberapa studi dan penelitian komunikasi partisipatif tidak berjalan sesuai harapan. Prinsip pembangunan yang bersifat "top down" masih kental terasa, sehingga banyak program yang tidak benar-benar menjadi kebutuhan masyarakat dan tingkat 
partisipasi rendah. Berbagai program pemerintah berhasil dalam aspek teknis, namun jarang berhasil dalam memberdayakan masyarakat. Pembangunan yang demikian akan menyebabkan ketergantungan masyarakat kepada pemerintah.

Pembangunan pertanian padi di Kabupaten Pandeglang merupakan sudah sepatutnya menjadi perhatian utama pemerintah. Upaya pembangunan pertanian dalam peningkatan produktivitas padi, sekaligus menjaga kelestarian lingkungan salah satunya dapat dilakukan melalui pengembangan pertanian padi organik. Berdasarkan hasil penelitian didapat bahwa pertanian padi organik memiliki tingkat nyata hingga 90 persen dalam upaya peningkatan produktivitas padi yang memperhatikan empat faktor utama, yaitu luas lahan, benih, air dan tenaga kerja (Novianto \& Setyowati 2009). Berdasarkan hasil penelitian yang dilakukan oleh Widiarta et al. (2011) menjelaskan bahwa keberlanjutan ekonomi petani dipengaruhi secara signifikan melalui praktik pertanian organik. Walaupun dapat dikatakan biaya input usaha tani padi organik relatif lebih besar dari usaha tani konvensional, namun hasil penelitian pada setiap $0,24 \mathrm{ha}$ /musim membuktikan bahwa penerimaan rataan usaha tani organik jauh lebih besar dibandingkan usaha tani metode konvensional. Selain itu, jika dilihat dari keuntungan rataannya yaitu usaha tani padi organik jauh lebih besar dibandingkan konvensional.

Beberapa hasil penelitian menjelaskan keuntungan dari pertanian padi organik. Petani memperoleh peningkatan produktivitas maupun keberlanjutan ekonomi, jika menerapkan pertanian padi organik. Pada kenyataannya sedikit sekali petani mengadopsi pertanian padi organik yang disebabkan oleh beberapa hal seperti, (1) petani berfikir pragmatis, terdapat gap dalam kemudahan praktik pertanian organik dengan pertanian konvensional; (2) petani belum menyadari pentingnya pertanian organik untuk kelestarian lingkungan; (3) petani merasa kurang puas terhadap tampilan warna hijau daun tanaman organik dibandingkan pertanian konvensional; (4) petani merasa tidak ada keterjaminan bebas hama dengan mempraktikan pertanian organik; (5) petani kesulitan dalam memperoleh pasokan pupuk dan proses pemupukannya; (6) sebagian besar petani berstatus buruh tani yang mengejar hasil maksimal dan waktu cepat; (7) sumber air irigasi sudah banyak tercemar dengan air irigasi pertanian konvensional; (8) hasil panen pertanian organik dirasa lebih sedikit dari pada konvensional (Widiarta et al. 2011). Salah satu upaya yang dapat dilakukan 
untuk mengatasi masalah rendahnya adopsi pertanian padi organik adalah melakukan pendekatan komunikasi partisipatif. Seperti yang dilakukan oleh salah satu lembaga nirlaba atau non-profit oriented organisazation yang bernama Lembaga Sosial Kemanusiaan Harapan Dhuafa (Pandhu).

Pandhu memiliki visi dan misi pembangunan dan pengembangan kemandirian masyarakat. Pandhu memiliki cabang di Kabupaten Pandeglang, Provinsi Banten. Aktivitas Pandhu di antaranya meliputi pengumpulan dana untuk bantuan masyarakat, pembangunan dan pemberdayaan masyarakat melalui di bidang pendidikan, lingkungan, kesehatan, sosial dan ekonomi. Pandhu mengedepankan masyarakat sebagai subyek pembangunan dalam upaya pemecahan permasalahan sosial. Pandhu memposisikan diri sebagai fasilitator, katalisator, maupun komunikator dalam pembangunan. Banyak program pembangunan Pandhu yang bersinggungan langsung dengan masyarakat tergolong miskin berkaitan dengan pemcahan masalah di bidang ekonomi, pendidikan, lingkungan, kesehatan dan program kemanusiaan lainnya. Pendekatan komunikasi Program-program pembangunan yang dilakukan oleh Pandhu menggunakan pendekatan komunikasi partisipatif agar tercapainya kemandirian dan keberlanjutan manfaat kepada penerima manfaatnya.

Salah satu program Pandhu adalah program pengembangan padi organik SRI. Program padi organik SRI berada di bawah divisi Environmental Service Program (ESP). Dilihat dari prospek program pengembangan padi organik SRI diharapan dapat meningkatkan pendapatan petani dari sisi ekonomi dalam jangka pendek hingga menengah dan dalam jangka panjang diharapkan dapat meningkatkan kesehatan masyarakat dengan konsumsi padi tanpa pupuk/pestisida sintetik serta menjaga kelestarian lingkungan dengan mempertahankan mutu lahan berserta ekosistemnya. program padi organik SRI merupakan salah satu cikal bakal terwujudnya kewirausahaan sosial di bidang pertanian dimana pada program ini terdapat motif ekonomi serta motif sosial yang dilakukan oleh masyarakat melalui inovasi-inovasi dan kearifan lokal yang diterapkan. Hal ini sesuai dengan pernyataan Wibowo dan Nulhaqim (2015) bahwa wirausaha sosial terwujud dari sebuah gerakan dengan misi sosial, melalui upaya-upaya menemukembangkan peluang yang ada disekitarnya dengan memanfaatkan teknologi, inovasi dan proses belajar yang ada disekitar, meskipun bertindak dengan dukungan sumber daya yang kurang memadai. Didorong 
oleh generasi baru pragmatis, keinovasian, aktivis sosial visioner dan jaringannya, kewirausahaan sosial menggabungkan bisnis campuran, amal, dan model gerakan sosial untuk mengkonfigurasi ulang solusi untuk masalah masyarakat dan memberikan nilai sosial baru berkelanjutan (Nicholls \& Alex 2006).

Konsep kewirausahaan sosial berupaya mencari titik keseimbangan profit dan social motive, yang artinya suatu wirausaha sosial mengupayakan keuntungan maksimal dengan tetap mempertimbangkan misi sosial dalam setiap aktivitasnya (Lubis 2011). Pandhu cabang Pandeglang menjalankan sebuah program pengembangan usaha tani padi organik dengan menerapkan system of rice intensification (SRI) di beberapa desa mitra, salah satunya, Desa Parigi, Kecamatan Saketi, Kabupaten Pandeglang, Provinsi Banten. Proses yang dijalankan Pandhu dalam mengembangkan program tersebut yaitu dengan melakukan pelatihan dan praktik padi organik SRI kepada perwakilan petani di Desa Parigi. Proses ini penting dilakukan agar dapat menarik partisipasi petani melakukan pertanian padi organik dalam mencapai kesejahteraan petani baik secara ekonomi, lingkungan, maupun kesehatan. Karakteristik individu petani penerima manfaat merupakan salah satu faktor utama dalam keberlangsungan pengembangan pertanian padi organik hingga tercapainya usaha tani yang berkelanjutan. Usaha tani berkelanjutan menitikberatkan pada peningkatan pendapatan petani secara ekonomi dan memperhatikan aspek kesehatan serta lingkungan secara sosial. Output yang diharapkan dari usaha tani ini yaitu terbentuknya karakter petani maupun kelembagaan usaha tani yang berjiwa kewirausahaan sosial. Selain itu, dalam proses pengembangan kewirausahaan sosial ini faktor yang tidak kalah pentingnya yaitu komunikasi partisipatif yang dilakukan oleh Pandhu kepada petani dalam menyampaikan program pengembangan masyarakat agar dapat meningkatkan partisipasi masyarakat dalam program pengembangan pertanian padi organik tersebut. Berdasarkan data empiris yang dikumpulkan oleh Pandhu bahwa terdapat peningkatan pendapatan yang nyata pada Kelompok Tani Barokah Tani, Batu Catok, Subur Tani dan Berkah Tani di Desa Parigi, Kecamatan Saketi yang dibentuk sejak tahun 2012. Hal ini dapat dilihat dari rataan penghematan modal usaha tani padi sebesar 68,75 persen dan rataan peningkatan produksi padi 75,05 persen. Manfaat lain yang dirasakan petani penerima manfaat 
program yaitu terjadinya peningkatan mutu lahan pertanian, hal ini dirasakan petani penerima manfaat berdasarkan pengalamannya selama bertani padi organik.

Berdasarkan pemaparan permasalahan penelitian, tinjauan kepustakaan, dan tinjauan hasil penelitian terdahulu, perlu dikaji lebih lanjut penelitian yang terkait dengan pengembangan kewirausahaan sosial melalui aktivitas komunikasi partisipatif, sehingga secara implisit maupun eksplisit didapatkan perumusan masalah yaitu 'bagaimana komunikasi partisipatif dalam pengembangan Kewirausahaan Sosial di Pandeglang, Banten?'. Sehingga, dari pertanyaan penelitian tersebut didapat Tujuan penelitian ini yaitu untuk mengetahui komunikasi partisipatif dalam pengembangan Kewirausahaan Sosial di Pandeglang, Banten.

\section{METODOLOGI}

Pendekatan penelitian menggunakan metode penelitian kombinasi atau metode perpaduan antara metode penelitian kuantitatif dengan kualitatif. Sugiyono (2013) menjelaskan metode penelitian kombinasi, yaitu metode penelitian yang berlandaskan pada filsafat pragmatisme atau kombinasi antara positivisme dan postpositivisme untuk meneliti pada kondisi obyek alamiah maupun buatan, dimana peneliti dapat menjadi instrumen serta menggunakan instrumen dalam penelitian. Selain itu, analisis data bersifat induktif dan deduktif, selanjutnya hasil penelitian kombinasi dapat juga digunakan untuk memahami makna. Tujuan dari penggunaan metode penelitian kombinasi ini yaitu untuk mendapatkan hasil penelitian yang lengkap. Peneliti memperoleh data kuantitatif dan kualitatif pada waktu bersamaan. Yaitu data diperoleh pada saat mewawancara responden dan bersamaan dengan pengisian kuesioner. Wawancara yang dilakukan sifatnya hanya hanya untuk melengkapi data kuesioner. Teknik ini juga menurut Singaribun (1995) dalam Krisyantono (2010) disebut semikuantitatif-kualitatif.

Teknik pengumpulan data penelitian kuantitatif dilakukan dengan teknik sensus, yaitu mengambil contoh yang merupakan populasi dengan menggunakan kuesioner sebagai alat pengumpulan data pokok. Selain itu, pengumpulan data juga menggunakan metode observasi berupa pengamatan dan pencatatan secara teliti dan sistematis atas gejala-gejala yang sedang diteliti (Muljono 2012). Berdasarkan data 
penerima manfaat program padi organik SRI yang dilaksanakan oleh Pandhu, total penerima manfaat di Kabupaten Pandeglang 186 orang. Fokus lokasi penelitian (purposive) dilakukan di Desa Parigi, Kecamatan Saketi dengan jumlah anggota kelompok tani penerima manfaat program padi organik SRI sebanyak 56 orang dari Kelompok Tani Barokah Tani, Batu Catok, Subur Tani dan Berkah Tani. Sebaran populasi dan contoh penelitian terdapat pada Tabel 1.

Data yang terkumpul dianalisis dengan menggunakan analisis statistik deskriptif. Analisis secara deskriptif dilakukan dengan menggunakan tabel distribusi frekuensi dan persentase data primer yang diperoleh dari wawancara petani penerima manfaat (PPM) menggunakan kuesioner.

Tabel 1 Sebaran Populasi dan Contoh Penelitian

\begin{tabular}{rlcr}
\hline No & \multicolumn{1}{c}{ Kelompok Tani } & Populasi (orang) & Contoh (orang) \\
\hline 1 & Barokah Tani & 13 & 13 \\
2 & Batu Catok & 15 & 15 \\
3 & Subur Tani & 15 & 15 \\
4 & Berkah Tani & 13 & 13 \\
\hline & Total & 56 & 56 \\
\hline
\end{tabular}

Sumber : Harapan Dhuafa

\section{HASIL DAN PEMBAHASAN}

\section{Komunikasi Partisipatif}

Indikator dari komunikasi partisipatif yaitu dengan melihat seberapa intens terjadinya dialog, voice, liberating pedagogy, dan action-reflection-action dalam setiap kegiatan penyuluhan maupun pelatihan program padi organik SRI yang dilakukan oleh Pandhu. Kegiatan penyuluhan atau pelatihan tersebut dilakukan secara intensif oleh seorang fasilitator Pandhu melalui kegiatan sekolah lapang SRI (belajar di kelas dan praktik di lahan), selanjutnya dilakukan pembentukan kelompok tani SRI organik dan melakukan pertemuan rutin dalam penguatan tani SRI organik dan pengembangan pertanian padi organik oleh fasilitator. Berdasarkan hasil wawancara 
dengan responden petani penerima manfaat (PPM) program padi organik SRI didapat intensitas komunikasi partisipatif yang dapat dilihat pada Tabel 2.

Tabel 2 Kategori, Jumlah dan persentase responden di Desa Parigi menurut indikator intensitas komunikasi partisipatif

\begin{tabular}{|c|c|c|c|c|}
\hline \multirow{2}{*}{ No } & \multirow{2}{*}{ Intensitas Komunikasi Partisipatif } & \multirow{2}{*}{ Kategori } & \multicolumn{2}{|c|}{ Jumlah Responden } \\
\hline & & & Orang & $\%$ \\
\hline \multirow[t]{3}{*}{1} & Dialog & Rendah & 0 & 0,00 \\
\hline & & Sedang & 24 & 42,86 \\
\hline & & Tinggi & 32 & 57,14 \\
\hline \multirow[t]{3}{*}{2} & Voice & Rendah & 0 & 0,00 \\
\hline & & Sedang & 15 & 26,79 \\
\hline & & Tinggi & 41 & 73,21 \\
\hline \multirow[t]{3}{*}{3} & liberating pedagogy & Rendah & 0 & 0,00 \\
\hline & & Sedang & 1 & 1,79 \\
\hline & & Tinggi & 55 & 98,21 \\
\hline \multirow[t]{3}{*}{4} & action-reflection-action & Rendah & 0 & 0,00 \\
\hline & & Sedang & 13 & 23,21 \\
\hline & & Tinggi & 43 & 76,79 \\
\hline
\end{tabular}

Sumber : Hasil olahan data primer

Pada tahap sekolah lapang PPM di berikan edukasi tentang kondisi lahan, manfaat pertanian SRI organik, dilatih cara pembuatan pupuk kompos, pupuk cair, penanganan hama penyakit, hingga cara budidaya padi organik metode SRI selama sepekan. Lebih intens lagi pelatihan dilakukan di lahan demplot agar PPM lebih memahami dan melihat secara langsung teknik budidaya pertanian padi organik metode SRI dari penyemaian hingga panen. Selanjutnya. hasil panen dari demplot dievaluasi bersama-sama, sehingga PPM mengetahui kekurangan maupun kelebihan dari demplot yang telah dikerjakan bersama-sama. Pada tahap sekolah lapang ini PPM diajak berinteraksi antara menyuluh dengan PPM maupun sesama PPM. Interaksi ini merupakan berupa dialog dan berpendapat terkait pengalaman berusaha tani PPM. Tahap pembebasan pedagogi dan aksi-refleksi terjadi saat PPM mempraktikan hasil 
belajar di lahan demplot. PPM lebih aktif bertanya kepada penyuluh dalam setiap pertemuan, karena selain menjadi ajang belajar juga sebagai ajang konsultasi permasalahan pertanian di lahan masing-masing. Disampaikan oleh fasilitator bahwa PPM sangat antusias dalam mengikuti setiap tahapan pendampingan. Hal ini sesuai dengan yang disampaikan Salah satu anggota kelompok Berkah Tani Ibu Er di Kp. Antigati, berikut:

"Saya selalu hadir dan aktif bertanya jika ada pelatihan dari Pandhu karena ingin mendapatkan ilmu bertani baru..."

Anggota kelompok tani lainnya pun antusias menghadiri dan belajar tentang pertanian padi organik metode SRI, meskipun jarak dan kesempitan waktu, seperti yang dialami Ibu Ro anggota kelompok Batu Catok di Kp. Mangong, berikut:

"Meskipun jarak ke lokasi pelatihan cukup jauh dan ditempuh dengan berjalan, tapi kami tetap semangat hadir untuk ingin belajar cara pertanian padi organik metode SRI"

Komunikasi partsipatif yang dibangun oleh Pandhu yang dilihat dari tingkat intensitasnya yaitu terbilang sangat tinggi. Hal ini membuktikan bahwa proses komunikasi dalam program padi organik SRI menekankan pada komunikasi dua arah atau dapat dikatakan pula antara sumber dan penerima pesan tidak terdapat perbedaan dalam mencapai tujuan komunikasi. Selain hasil tabulasi yang menunjukan intensitas komunikasi partisipatif yang tinggi, hasil wawancara mendalam terhadap PPM dan pihak terkait seperti, aparatur desa, ketua kelompok tani dan gabungan kelompok tani, serta penyuluh pertanian lapang (PPL) Dinas Pertanian, menyebut intensitas komunikasi partisipatif terjadi juga karena antusias PPM yang terdorong dari tujuan meningkatkan tarah hidup yang inginkan bersama.

Model komunikasi yang dijalankan oleh Pandhu dalam setiap programnya selalu menekankan pada model komunikasi yang konvergen untuk mencapai pemahaman bersama dan partisipasi masyarakat. Dalam mencapai kesepahaman bersama melalui forum musyawarah, komunikasi model konvergensi dianggap lebih efektif dan efisien karena Model komunikasi ini lebih mengutamakan sistem dialog interaktif yang berarti masyarakat terlibat dan berpartispasi aktif dalam suatu program tersebut. Dalam program padi organik SRI ini model komunikasi konvergen sangat 
penting dan menunjang keberhasilan pembangunan agat petani penerima manfaat dapat mencapai kesepahaman bersama untuk menjalankan dan mencapai tujuan program padi organik SRI yaitu peningkatan taraf hidup petani dan misi sosial lainnya.

\section{Manfaat program padi organik SRI}

Manfaat progam padi organik SRI dirasakan memberikan banyak manfaat bagi PPM karena kegiatan seperti ini dirasa baru dan menjadi pelajaran berharga dalam menjalankan tani padi khususnya dengan sistem SRI organik. Hal ini sejalan dengan Rogers (2003) tentang teori karakteristik adopsi inovasi yang menjeslakan bahwa inovasi merupakan suatu ide, praktis, atau sesuatu yang dipersepsikan baru oleh orang atau unit adopsi yang lain. Berdasarkan teori tersebut, indikator persepsi terhadap inovasi program padi organik SRI yaitu keuntungan relatif (tingkat keuntungan langsung maupun tidak langsung), kompatabilitas (tingkat kesesuaian dengan budaya yang ada), kompleksitas (tingkat kesulitan inovasi), eksperimental (tingkat kemudahan dalam mengaplikasikan inovasi), dan observatif (hasil inovasi dapat dilihat di lingkungan sekitarnya). Persepsi manfaat program padi organik SRI berdasarkan teori katakteristik inovasi yang dirasakan oleh PPM sekaligus membantu menjelaskan tingkatan berbeda dalam adopsi inovasi dapat dilihat pada Tabel 3.

Tabel 3 Kategori, Jumlah dan Persentase Responden Di Desa Parigi Menurut Persepsi Kemanfaatan Program

\begin{tabular}{|c|c|c|c|c|}
\hline \multirow{2}{*}{ No } & \multirow{2}{*}{ Persepsi Manfaat Program } & \multirow{2}{*}{ Kategori } & \multicolumn{2}{|c|}{ Jumlah Responden } \\
\hline & & & Orang & $\%$ \\
\hline \multirow[t]{3}{*}{1} & Keuntungan Relatif & Rendah & 0 & 0,00 \\
\hline & & Sedang & 13 & 23,21 \\
\hline & & Tinggi & 43 & 76,79 \\
\hline \multirow[t]{3}{*}{2} & Kompatibilitas & Rendah & 0 & 0,00 \\
\hline & & Sedang & 29 & 51,79 \\
\hline & & Tinggi & 27 & 48,21 \\
\hline \multirow[t]{3}{*}{3} & Kompleksitas & Rendah & 3 & 5,36 \\
\hline & & Sedang & 48 & 85,71 \\
\hline & & Tinggi & 5 & 8,93 \\
\hline
\end{tabular}


$4 \quad$ Eksperimental

5 Observatif

$\begin{array}{lrr}\text { Rendah } & 2 & 3,57 \\ \text { Sedang } & 11 & 19,64 \\ \text { Tinggi } & 43 & 76,79 \\ \text { Rendah } & 41 & 73,21 \\ \text { Sedang } & 9 & 16,07 \\ \text { Tinggi } & 6 & 10,71\end{array}$

Sumber : Hasil olahan data primer

Kemanfaatan program padi organik SRI utamanya dapat dirasakan mitra petani berdasarkan keuntungan relatifnya dari inovasi tersebut. Keuntungan relatif berdasarkan Tabel 3 sangat tinggi, yaitu 76,79 persen responden merasakan manfaat dari program tersebut. Persepsi manfaat program dengan bertani padi organik metode SRI, yaitu peningkatan produktivitas padi, penghematan biaya input produksi, dampak baik terhadap kesuburan lahan, dampak terhadap kesehatan, dan mafaat lainnya. Peningkatan produktivitas padi yang dirasakan petani yaitu 20-40 persen. Rataan produktivitas padi di Desa Parigi adalah 4-6 ton/ha seperti yang disampaikan oleh ketua Gapoktan Pulosari, berikut:

"Produktivitas padi di Desa Parigi rata-rata 4-6 ton/ha, hal ini karena kondisi persawahan yang berada di daerah pergunungan, sehingga lahan banyak terpakai untuk pematang sawah dan irigasi, sedangkan peningkatan hasil panen sekitar 2040 persen dilihat dari hasil panen lahan saya dari $10 \mathrm{kw}$ menjadi $12 \mathrm{kw}$

Penghematan biaya input produksi hanya diperoleh melalui tidak membelinya pupuk urea yang dirasa cukup tinggi, petani cukup memanfaatkan bahan organik yang ada di sekitar seperti jerami, kotoran ternak, dan bahan MOL yang banyak ditemukan di sekeliling lahan. Namun seiring berjalannya waktu, masyarakat sudah memahami pemanfaatan pupuk kompos dan kandang, maka bahan-bahan pupuk seperti jerami, kotoran ternak, dan bahan pembuatan MOL sudah memiliki nilai ekonomi, sehingga terjadi kesulitan dalam memperoleh bahan-bahan tersebut. Seperti yang didampaikan oleh ketua Kelompok Barokah Tani sekaligus pengelola Rumah APPO berikut:

"Jaman dulu jerami dibakar dan tidak ada manfaatnya, sekarang setelah ada pelatihan atau pembekalan dari Pandhu jerami dan kotoran ternak juga sudah 
dapat termanfaatkan dengan baik untuk pupuk kompos bahkan menjadi bahan yang rebutan serta memiliki nilai ekonomi"

Bertani padi organik metode SRI juga dirasakan manfaatnya oleh mitra petani yaitu berupa perbaikan dan mempertahankan kesuburan lahan pertanian yang dapat dirasakan melalui indikator penggemburan lahan sawah, munculnya hewan penggembur tanah seperti cacing, belut dan lainnya. Berikut disampaikan oleh salah satu anggota Barokah Tani tentang kondisi lahan sawah yang ditanam padi organik metode SRI:

"Kalau pakai pupuk kimia lahan menjadi keras dan dangkal, tapi setelah bertani padi organik lahan saya sudah tidak dangkal lagi dan lingkungan sawah menjadi hidup karena banyak jalur cacing yang ada dilahan serta banyak belut"

Pengambilan keputusan mitra petani dalam adopsi inovasi juga dipengaruhi kesesuaian (compatability) inovasi dengan norma-norma sosial yang ada di masyarakat. Tabel 3 menunjukkan sebesar 51,79 persen responden menyatakan kesesuaian inovasi (pertanian padi organik metode SRI) cukup sesuai dengan norma-norma sosial masyarakat dan sisanya menjawab sangat sesuai $(48,21$ persen). Hal tersebut mengindikasikan bahwa persepsi masyarakat terhadap inovasi tersebut dinilai positif atau baik. Secara budaya, bertani padi organik metode SRI sudah sesuai karena notabennya mitra petani merupakan petani, namun secara letak geografis belum sesuai, karena sebagian Mitra Petani hanya memiliki lahan kebun, sehingga pertanian padi organik metode SRI belum secara optimal diterapkan. Berikut disampaikan oleh fasilitator Pandhu:

“... seperti di Mangong, hasil pelatihan pupuk organik diterapankan pada usaha tani palawija, seperti cabe, pepaya, bahkan tanaman tahunan seperti cengkeh, melinjo, dan lainnya mulai dipupuk organik"

Secara umum terdapat tujuh prinsip (kaidah) usaha tani padi organik metode SRI yang dikembangkan yaitu: (1) Pengolahan tanah dan pemupukan dengan kompos organik, (2) benih yang bermutu dan ditanam berumur muda, (3) penanaman benih tunggal dan langsung, (4) jarak tanam yang cukup lebar, (5) tidak mengunakan pupuk kimia, (6) penggunaan air yang efisien dan (7) pengendalian hama dilakukan secara terpadu tanpa penggunaan pestisida dan bahan-bahan sintetik. Pertanian padi organik 
metode SRI dirasa Mitra Petani cukup sulit dalam penerapannya jika dilihat dari hasil wawancara pada Tabel 3 menyatakan sebesar 85,71 responden menyatakan cukup kompleks penerapan inovasi tersebut. Kompleksitas yang dirasakan Mitra Petani tersebut berkaitan dengan kendala dalam penerapan inovasi yaitu pengendalian hama keong cukup berisiko jika ditanam tunggal, pembagian waktu bagi buruh tani, sehingga pengurusan lahan dan tanaman tidak intensif, lokasi lahan yang cukup jauh akna berpotensi menimbulkan biaya angkut pada pupuk organik, dan kebiasaan instan Mitra Petani yang masih melekat menggunakan pupuk kimia. Hasil kajian Sugarda et al. (2008) di Jawa Barat mengungkapkan bahwa petani belum menerapkan secara ideal prinsip pertanian padi metode SRI yang dikarenakan oleh faktor-faktor sebgai berikut: (1) terlalu rumit; (2) serangan hama penyakit sulit dikendalikan; (3) pupuk organik sulit diperoleh atau mahal; (4) pertumbuhan tanaman terhambat; (5) kurangnya pendampingan; (6) sifat petani yang ingin selalu mencoba; (7) intensifnya pemeliharaan; dan (8) kesibukan kerja di sektor lain. Ketua Gapoktan Pulosari mengungkapkan pendapatnya sebagai berikut:

"SRI sangatlah hebat hasilnya bagi orang yang totalitas dalam perawatannya, namun bagi orang yang males, SRI tidak cocok"

Tingkat penerapan pertanian padi organik metode SRI belum optimal. Pada tahap awal Mitra Petani sangat antusias menanam padi organik karena manfaat yang yang dirasakan. Namun kondisi tersebut tidak bertahan lama. Banyak faktor menjadi kendala dalam keberlanjutan pertanian padi organik metode SRI berdasarkan pemaparkan sebelumnya. Faktor utama yang mempengaruhi PPM dalam menjalankan usaha tani padi organik SRI ini yaitu dapat memberikan nilai ekonomi lebih. Belajar dari pengalaman, Kelompok Berkah Tani memproduksi padi organik metode SRI sebanyak 2 ton, namun hasil usaha petani tidak mendapat hasil yang sesuai, malah terjual dengan harga sama dengan padi hasil pertanian konvensional. Hal ini sesuai dengan penelitian Jumna (2015) yang menjelaskan tentang kriteria pemasaran sebagai prioritas utama mencerminkan bahwa pengembangan usaha tani padi organik di Kabupaten Sragen sangat erat kaitannya dengan masalah pemasaran. Faktor penghambat strategi pengembangan usaha tani padi organik di Kecamatan Sambirejo, Sragen adalah hambatan hubungan kemitraan antara kelompok tani dengan pedagang besar padi organik. Kendala utama pemasaran merupakan menjadi perhatian utama 
petani, Pandhu, maupun pemerintah yang harus diselesaikan. Menurut keyakinan ketua Gapoktan Pulosari berpendapat:

"Cara pengembangan SRI organik yaitu dengan memperhatikan harga dan pasarnya, semakin banyak pemasaran maka orang mau bertani padi organik, jika harga dan pasar sudah sesuai maka peningkatan kesehatan dan lingkungan akan mengikuti"

\section{Tingkat Kewirausahaan Sosial}

Pada penelitian ini, peneliti berasumsi bahwa petani mitra atau PPM program pertanian organik SRI ini merupakan wirausahawan sosial di bidang pertanian. Adapun misi sosial dari kewirausahaan sosial dibidang pertanian padi organik ini adalah memcahkan masalah ekonomi, lingkungan dan kesehatan masyarakat. Oleh sebab itu, komunikasi partisipatif melalui pelatihan atau sekolah lapang pertanian padi organik yang dilaksanakan oleh Pandhu merupakan upaya yang dapat dilakukan agar pengembangan kewirausahaan sosial di bidang pertanian dapat terwujud. Namun perlu diidentifikasi juga setiap individu memiliki tingkat kewirausahaan sosial yang berbeda, sehingga perlu diketahui tingkat kewirausahaan petani atau PPM.

Indikator tingkat kewirausahaan terdiri empat indikator yang melekat pada seseorang atau lembaga yang meliputi, (1) manfaat sosial, (2) agen perubahan), (3) inovasi sosial, dan (4) aktivitas ekonomi (Hulgard 2010). Dalam penelitian ini fokus penelitian tingkat kewirausahaan sosial pada individu, sehingga penilaian juga dilihat pada karakter individu yang melekat sehari-hari, terlebih dengan adanya program padi organik SRI. Penilaian tingkat kewirausahaan sosial perlu melibatkan orang yang mengetahui karakter Mitra Petani sebelum dan sesudah dilakukan program. Penilaian tingkat kewirausahaan sosial dibantu oleh ketua-ketua kelompok tani.

Berdasarkan hasil wawancara dengan responden (PPM) program padi organik SRI didapat jumlah dan persentasi tingkat kewirausahaan sosial yang dapat dilihat pada Tabel 4 .

Tabel 4. Kategori, Jumlah dan Persentase Responden di Desa Parigi Menurut Tingkat Kewirausahaan Sosial

\begin{tabular}{llll}
\hline & Ningkat Kewirausahaan Sosial & Kategori & \multicolumn{2}{c}{ Jumlah Responden } \\
\cline { 3 - 3 } & & Orang & $\%$ \\
\hline
\end{tabular}




\begin{tabular}{lllrr}
\hline & & & & \\
\hline 1 & Manfaat Sosial & Rendah & 1 & 1,79 \\
& & Sedang & 26 & 46,43 \\
& \multirow{2}{*}{ Agen Perubahan } & Tinggi & 29 & 51,78 \\
& Rendah & 0 & 0,00 \\
& Sedang & 28 & 50,00 \\
& Inovasi Sosial & Tinggi & 28 & 50,00 \\
& & Rendah & 2 & 3,58 \\
& Aktivitas Ekonomi & Sedang & 27 & 48,21 \\
& Tinggi & 27 & 48,21 \\
& Rendah & 0 & 0,00 \\
& Sedang & 28 & 50,00 \\
& & Tinggi & 28 & 50,00 \\
\hline
\end{tabular}

Sumber : Hasil olahan data primer

Tabel 4 menggambarkan secara keseluruhan tingkat kewirausahaan sosial yang melekat pada setiap Mitra Petani memiliki jumlah dan persentasi berimbang pada kategori sedang dan tinggi. Hal ini menggambarkan pula Mitra Petani sudah cukup tinggi memiliki jiwa kewirausahaan sosial, sehingga potensi dalam pengembangan usaha tani padi organik metode SRI di Desa Parigi dapat dikatakan cukup tinggi. Tingkat kewirausahaan sosial setiap Mitra Petani juga dipengaruhi pada karakter dasar yang dimiliki seperti status sosial di masyarakat. Hal ini juga menjadi pertimbangan Pandhu dalam melakukan pendekatan kepada tokoh-tokoh masyarakat di Desa Parigi, sehingga tujuan program padi organik SRI dapat tercapai dengan baik.

Program padi organik SRI telah memberikan manfaat bagi Mitra Petani, terutama peningkatan dalam hal edukasi dan kemampuan bertani padi organik SRI. Pendampingan pada program padi organik SRI yang dilakukan oleh Pandhu kepada PPM dirasa cukup memberikan manfaat. Program ini akan tidak menjadi berarti tanpa diaplikasikan oleh PPM maupun diteruskan kepada petani lainnya melalui knowledge sharing. Hasil dan mafaat dari program padi organik SRI yaitu mencakup perbaikan ekosistem (lingkungan) pertanian dengan pemanfaatan bahan lokal untuk pupuk kompos maupun pertisida alami. Selain itu, manfaat lainnya adalah beberapa anggota kelompok Barokah Tani telah mahir bertani padi organik SRI dan mampu melatih 
kelompok tani lainnya, sehingga manfaat sosial yang terbangun tersebut memberikan dampak luas bagi masyarakat sekitar.

Pendekatan komunikasi yang dilakukan oleh Pandhu sudah efektif yaitu melalui pendekatan menyeluruh di Desa Parigi. Sehingga proses adopsi inovasi tersebut yang dilaksanakan Pandhu dapat berjalan dengan baik. Pihak desa pun merasa terbantu dan bersyukur dengan adanya kerjasama dan dukungan Pandhu dalam melaksanakan program-programnya di Desa Parigi. Berikut disampaikan oleh salah satu aparatur Desa Parigi:

“...Jadi emang bagus sih, jadi Pandhu sangat membantu desa, seperti pelatihan dan pengetahuan kepada petani sangat membantu dan sudah sesuai dengan kebutuhan, seperti pembangunan infrastruktur pembangunan air, program Pandhu selalu tuntas dari awal sampai akhir, berbeda dengan program pemerintah..."

Pemilihan dan pembentukan kelompok tani di Desa Parigi berdasarkan hasil seleksi dan tahap analisis yang dilakukan oleh fasilitator Pandhu. Peran fasilitator Pandhu di desa, yaitu melakukan pendekatan personal kepada stakeholder maupun ke masyarakat scara terus menerus. Tahap awal penentuan wilayah dampingan fasilitator melakukan pemetaaan sosial dan pemetaan aset bersama warga setempat. Berikut disampaikan oleh fasilitator Pandhu di Desa Parigi:

"Sebelum merealisasikan program kami biasanya menganalisis calon penerima manfaat, lalu dilakukan pembentukan kelompok dampingan, setelah terbentuk maka kami melakukan pendampingan, monitoring dan evaluasi scara rutin, biasanya dua kali dalam sebulan"

Pendekatan fasilitator yang dilakukan Pandhu terhadap stakeholder dilakukan bertujuan salah satunya agar mempermudah proses pendekatan dengan masyarakat secara luas. Stakeholder yang berperan utama dalam program-program Pandhu di Desa Parigi yaitu terbentuk dalam kelompok sosial yang saat ini bernama Kelompok Berkah Tani. Keanggotaan kelompok ini terdiri dari tokoh-tokoh masyarakat yang memiliki komitmen tinggi untuk melakukan perubahan sosial masyarakat Desa Parigi. Sebelum dilaksanakan program padi organik SRI, pada tahun 2006 Pandhu dan PCI (Project Concern International) menjalankan program kesehatan seperti Community Lead Total Sanitation (CLTS), Pembangunan Sarana Air Bersih (SAB), dan promosi kesehatan 
(Promkes). Program ini sukses dijalankan bersama stakeholder yang tergabung dalam kelompok Ekokes (ekonomi dan kesehatan) yang diketuai oleh ketua Gapoktan. Tim Ekokes melakukan penyadaran pentingnya membangun cubluk untuk kesehatan bersama. Alhasil, setiap rumah kini telah membangun cubluk sederhana maupun permanen tanpa subsidi dari manapun, namun kendala terbentur pada biaya dan mainset masyarakat, sekarang Desa Parigi sudah 100\% bebas dari perilaku buang air besar sembarangan (BABs). Berikut disampaikan oleh ketua Ekokes dalam proses penyadaran kesehatan masyarakat:

"Kita tim Ekokes membutuhkan waktu selama tiga bulan dalam proses penyadaran dan merubah pola pikir masyarakat menjadi partisipatif, sehingga muncul kegotongroyongan masyarakat baik tenaga, pikiran, maupun biaya"

Agen-agen perubahan inilah yang diharapkan dapat memicu perubahan sosial di Desa Parigi ke arah yang lebih baik. Program pertanian organik metode SRI diharapkan menjadi sebuah program pengembangan ekonomi, kesehatan, dan lingkungan yang dapat dilaksanakan masyarakat melalui agen-agen perubahan sosial bentukan Pandhu. Banyak faktor terbentuknya agen perubahan di Desa Parigi, salah satunya terjadi karena harapan dan tekad bersama untuk memajukan daerahnya. Hal ini senada dengan yang disampaikan oleh Dees dalam Seelos dan Mair (2004) Wirausaha sosial memainkan aturan dari agen perubahan pada sektor sosial: (1) Mengadopsi misi untuk menciptakan dan secara berkelanjutan manfaat sosial (tidak hanya manfaat pribadi); (2) Mengenali dan mengejar dengan cepat peluang baru untuk mencapai misi (sosial); (3) Melibatkan diri dalam sebuah proses inovasi, adaptasi, dan belajar berkelanjutan; (4) Bergerak dengan keterbatasan sumber daya; (5) Memperlihatkan rasa tanggungjawab tinggi kepada konstituen dan pada usaha-usaha untuk menghasilkan target yang telah ditetapkan.

Inovasi sosial dilakukan oleh PPM dan dipadukan dengan kearifan lokal. Tabel 4 menunjukan bahwa sebagian besar PPM melakukan inovasi sosial berupa implementasi program padi organik SRI yaitu sebesar 48,21 persen berkategori sedang dan tinggi, sedangkan sisanya terkategori rendah (3,58 persen).

Kearifan lokal yang masih berjalan dalam kegiatan pertanian di Kab. Padeglang dikenal dengan istilah liuran. Liuran adalah kegiatan gotongroyong kelompok 
masyarakat dalam pelaksanaan pengolahan lahan pertanian. Liuran ini dilaksanakan bergiliran dilahan pertanian kelompok masyarakat. Secara teknis liuran merupakan hasil kesepakatan kelompok, dimana pemilik lahan yang akan diolah lahannya melakukan negosiasi biaya pengolahan lahan berdasarkan luasan dan medannya, sedangkan untuk biaya konsumsi liuran disediakan oleh pemilik lahan. Hasil liuran ini dapat dimanfaatkan untuk keperluan bersama berdasarkan kesepakatan bersama. Sebagai contoh liuran yang dilaksanakan di Kampung Gunung Sunda yang berjumlah 20 orang. Liuran di Kampung Gunung Sunda disepakati hasilnya untuk kebutuhan masyarakat seperti acara keagamaan dan kemasyarakatan. Selain itu di tetapkan pula waktu pelasanaan liuran dilaksanakan setiap hari kamis dan punishment bagi anggota yang berhalangan hadir dengan membayar uang sebesar Rp 25.000,- atau mencarikan orang penggantinya. Anggota sepakat hasil liuran tahun ini akan dibelikan peralatan sound system untuk keperluan acara-acara keagamaan, pernikahan dan lainnya. Salah satu contoh kegiatan liuran yang dilaksanakan di lahan ketua kelompok Berkah Tani yang berukuran $\pm 0,5$ ha dan disepakati biaya pengolahan lahan sebesar $\operatorname{Rp} 1.300 .000,-$.

Berikut disampaikan oleh ketua kelompok Berkah Tani pada saat liuran dilaksanakan di lahan sawahnya:

"Jika mengandalkan tenaga sendiri pengolahan lahan akan selesai selama \pm 30 hari dan biayanya lebih besar, alhamdulilah berkat ada liuran jadi meringankan tenaga dan biaya saya"

Latar belakang PPM menjalankan pertanian padi organik SRI salah satunya adalah harapan keuntungan ekonomi yang didapatkan meningkat. Berdasarkan Tabel 4 hasil penilaian jumlah dan persentasi responden terhadap tingkat kewirausahaan, sebagian besar responden berkategori sedang (50 persen) dan tinggi (50 persen). Hal ini mengartikan bahwa secara rasional PPM menjalankan usaha tani padi organik SRI dengan mengharapkan peningkatan pendapatan, namun pada kenyataannya petani tetap berperilaku subsisten karena sebagian besar PPM berstatus petani buruh dengan ukuran lahan garan berkisar 0,1-0,25 ha.

\section{SIMPULAN DAN SARAN}

\section{Simpulan}


Komunikasi partisipatif dalam membangun pertanian padi organik metode SRI berdampak positif bagi pengembangan kewirausahaan sosial di Desa Parigi. Komunikasi yang partisipatif dan intensif baik pada saat pelatihan/sekolah lapang padi organik SRI maupun pertemuan rutin oleh fasilitator Pandhu, sehingga PPM menjadi aktif berdialog, berpendapat hingga merefleksikan hasil pelatihan/sekolah lapang di lahannya masing-masing. Nilai-nilai kewirausahaan sosial Mitra Petani juga diperoleh dari pelatihan/sekolah lapang pada program padi organik SRI, dimana PPM sangat memahami begitu pentingnya menjalankan usaha tani padi organik dengan metode SRI, selain bermanfaat secara ekonomi seperti mengurangi biaya input (bibit, pupuk, pestisida), juga meningkatkan pendapatan dan seiring dengan terjadinya peningkatan produktivitas padi, juga Mitra Petani merasa puas dan bangga dengan menjalankan pertanian padi organik SRI, mereka telah berkontribusi dalam peningkatan kualitas lingkungan serta kesehatan dengan memproduksi dan mengkonsumsi padi organik.

\section{Saran}

Potensi pengembangan kewirausahaan sosial melalui program padi organik SRI di Desa Parigi dirasa masih cukup tinggi. Hal utama yang perlu diperhatikan dalam menciptakan kewirausahaan sosial yaitu peningkatan daya dukung stakeholder pembangunan dari aspek regulasi (pemerintah daerah maupun pusat), aspek agribisnis dan pemasaran (perusahaan swasta) dan lembaga pemberdayaan masyarakat lainnya (non profit organization dan lembaga sosial lainnya). Sehingga diharapkan terciptanya integrasi dalam upaya peningkatan kesejahteraan petani melalui pengembangan usaha tani padi organik.

Saran bagi Pandhu sebagai mitra petani dalam pengembangan pertanian padi organik SRI di Desa Parigi yaitu dengan melanjutkan programnya kearah peningkatan nilai ekonomi usaha tani padi organik dengan melakukan pelatihan menejemen bisnis ataupun inkubator bisnis agar kelompok tani lebih siap mengimplementasikan pertanian padi organik dengan harapan meningkatnya taraf ekonomi petani.

\section{DAFTAR PUSTAKA}

Freire P. 2005. Pedagogy of the Oppressed. 30th Anniversary Edition Translated by Myra Bergman Ramos. New York (US): Continuum. 
Hadiyanto. 2008. Komunikasi pembangunan partisipatif: sebuah pengenalan awal. Jurnal Komunikasi Pembangunan. 6 (2): 80-88.

[Pandhu] Lembaga Sosial Kemanusiaan Harapan Dhuafa. 2016. Profil Lembaga dan Data Perkembangan Kelompok SRI. Environmental Services Program Yayasan Harapan Dhuafa Banten Cabang Pandeglang.

Hulgard L. 2010. Discourses of social entrepreneurship-variation of the same theme? Working Paper. WP no. 10/01. Belgia (BE): EMES European Research Network.

Jumna BK. 2015. Strategi pengembangan usaha tani dalam upaya peningkatan produksi padi organik di Kecamatan Sambirejo Kabupaten Sragen. Economics Development Analysis Journal. 4(3): 256-264

Krisyantono, Rachmat. 2010. Teknik Praktis Riset Komunikasi. Jakarta (ID): Kencana Prenada Media Group.

Liliweri A. 2011. Komunikasi Serba Ada Serba Makna. Jakarta (ID): Kencana.

Lubis RH. 2011. Transformasi tanggung jawab sosial perusahaan kepada kewirausahaan sosial. Jurnal Manajemen Usahawan Indonesia 40(6): 58-73

Mardikanto T. 2010. Komunikasi Pembangunan. Surakarta (ID): UNS Press

McPhail TL. 2009. Development Communication; Reframing the Role of the Media. London (UK): Willey-Blackwell Pub.

Muchtar K. 2016. Penerapan komunikasi partisipatif pada pembangunan di indonesia. Jurnal makna. 1(1): 20-32.

Muljono P. 2012. Metodologi Penelitian Sosial. Bogor (ID): IPB Press

Muslikhah FP. 2015. Komunikasi partisipatif pada kelompok wanita tani di Kecamatan Kajoran Kabupaten Magelang. [tesis]. Bogor (ID): IPB.

Nicholls, Alex. 2006. Social Entrepreneurship New Models of Sustainable Social Change. New York [US]: Oxford University Press

Novianto FW, Setyowati E. 2009. Analisis produksi padi organik di Kabupaten Sragen tahun 2008. Jurnal Ekonomi Pembangunan. 10(2): 267-288. 
Rogers EM. 2003. Difasilitatorusion of Innovation Fifth Edition. New York (US): Free Press.

Sugiyono. 2013. Metode Penelitian Kuantitatif, Kualitatif, dan Kombinasi (Mixed Methods). Bandung (ID): Alfabeta

Tufte T, Mefalopulos P. 2009. Participatory Communication: A Practical Guide. Washington (US): World Bank.

Wibowo H, Nulhaqim SA. 2015. Kewirausahaan Sosial Merevolusi Pola Pikir Menginisiasi Mitra Pembangunan. Bandung (ID): Unpad Press. internet. [Diunduh 20 Desember 2015]. Terdapat pada: http://pustaka.unpad.ac.id/wpcontent/uploads/2015/03/6-Kewirausahaan-Sosial.pdf

Widiarta A, Adiwibowo S, Widodo. 2011. Analisis keberlanjutan praktik pertanian organik di kalangan petani. Jurnal Transdisiplin Sosiologi, Komunikasi, dan Ekologi Manusia. 5(1): 71-89 